\title{
Consistency in gene-Alzheimer's disease association studies
} Javier Llorca, Trinidad Dierssen-Sotos, Onofre Combarros, José Berciano

$\mathrm{T}$ hroughout the past decade, a great number of studies have been published searching for a gene-disease association. Ioannidis et al, studying a variety of diseases, pointed out that the first time such a relation is shown it correlates moderately with later results.

Sporadic Alzheimer's disease (AD) has been extensively studied searching for gene causation. ${ }^{2}$ Apart from the well established relation with ApoE $\epsilon-4$ genotype, other gene candidates have weaker associations with $\mathrm{AD}$ and their role remains controversial. In fact, results from case-control studies are frequently contradictory and meta-analyses have been conducted to clarify whether a gene-AD association exists. ${ }^{3}$

The goal of this paper is to describe how the odds ratio between a gene and $\mathrm{AD}$ changes as new studies are published.

\section{METHOD}

We included case-control studies published before July 2003 on $\mathrm{AD}$ and the following polymorphisms: myeloperoxidase 7 (6 studies), ${ }^{4-8}$ low density lipoprotein receptor related protein gene (LRP) exon 3 polymorphism (10 studies), ${ }^{9-18}$ Glu298Asp polymorphism in the endothelial nitric oxide synthetase (NOS-3) (10 studies), ${ }^{816}{ }^{19-26}$ and cathepsin D (14 studies). ${ }^{8} 16$ 27-37 A study on LRP-AD association was excluded because it only reported allelic data. ${ }^{38}$ As this is a field in fast development, this list of genes is not intended to be exhaustive; we have selected them because, having worked on them, we knew they have been reported in more than five papers.

To select these papers, we searched in Medline for papers including in the text "Alzheimer" and any of the following: "myeloperoxidase", "cathepsin", "nitric oxide", "lipoprotein related-receptor", or "lrp". The search was completed revising the bibliography of the selected papers. The articles that were found were revised for selecting only case-control studies relating $\mathrm{AD}$ with any of the genes listed in the preceding paragraph. Papers were included if they reported crude results on gene-AD association (for example: a two by two table) or odds ratios with confidence intervals; we exclude papers reporting only allelic results (for example: allelic odds ratio or allelic distribution). We did not analyse the paper's quality, as this is not pertinent for the goal of our study.

For each gene-AD relation we performed a cumulative meta-analysis: we obtained an odds ratio with the first study, then we added the second published paper and we calculated a common odds ratio, and so on until all the articles were included in the same order they were published in. Common odds ratios were estimated weighting by the inverse of the variance in a random effect model. The statistical analysis was performed using the software Stata 8/SE (Stata Corporation, College Station, TX, US).

\section{RESULTS}

Figure 1 displays the evolution of the cumulative odds ratio for each gene. Only myeloperoxidase polymorphism had an initial odds ratio close to 1 , and suffered small changes when adding later studies. The LRP-exon 3 gene had the highest initial odds ratio (2.41); when adding further studies the cumulative odds ratio progressively decreased down to 1.35 . Similar changes may be seen for cathepsine D gene (its odds ratio changes from 2.40 to 1.26 ) and NOS-3 (its odds ratio falls from 1.72 to 1.07$)$.

\section{DISCUSSION}

Our results, similar to those reported by Ioannidis et al, ${ }^{1}$ suggest that the first study dealing with a gene-AD relation tends to overestimate this association. A possible explanation would be publication bias, leading to a delay in publication of studies with ORs closer to the null.

One of the main causes for publication bias is that papers with negative results (that is, no association) would have a higher probability of being rejected regardless of their scientific quality, while papers with novel positive results would be seen as more attractive and would be more likely to be published. ${ }^{39}$ While genetic epidemiology develops, a progressively higher number of genetic markers would be tested for gene-disease association, and more papers on this subject would compete for the limited space in scientific journals; the editors would, therefore, have to make a choice and, probably, papers with positive results hold the advantage. However, the probability of type I error rises as the proportion of studies with positive results increases.

Once a strong association has been described, studies with negative results would be published because they contradict the first report. Then, if the first paper was attributable to a type I error, the next results would tend towards the null hypothesis (that is, $\mathrm{OR}=1$ ).

Our gene selection is partial; therefore, we do not intend to establish our results as a kind of gold standard in the genedisease association, but as a called for scepticism facing the very first results on any genetic marker.

This layout is a challenge for researchers, referees, editors and, we believe, especially for readers. When a genetic marker is suggested as a putative cause for a disease, readers should have in mind the need for consistency in causation epidemiology. Consistency refers to the reliability of the results in different populations and under different circumstances, and is one of the causality criteria proposed by Hill and generally admitted. ${ }^{40}$ Before a gene-disease association is to be recognised as true, it is necessary to independently replicate investigations and, if needed, to combine their results in meta-analyses.

\section{ADDENDUM}

After sending the last version of our paper, a meta-analysis on association between cathepsin $\mathrm{D}$ and $\mathrm{AD}$ has appeared. ${ }^{41}$ It substantially coincides with our results and also remarks the dissipation of the postulated effect.

Abbreviations: $A D$, Alzheimer's disease; LDP, lipid related protein 
Study results
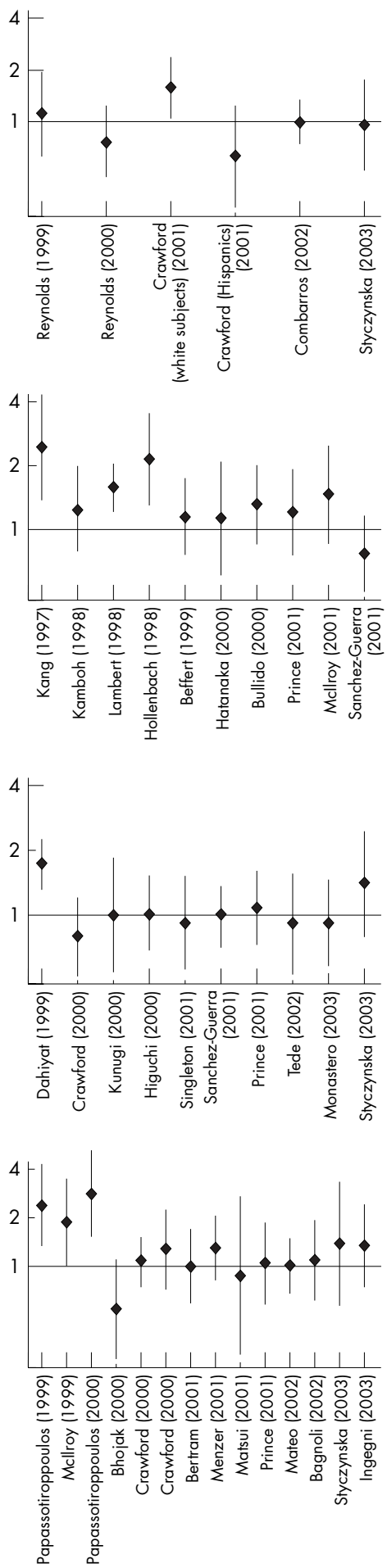

Meta-analysis results
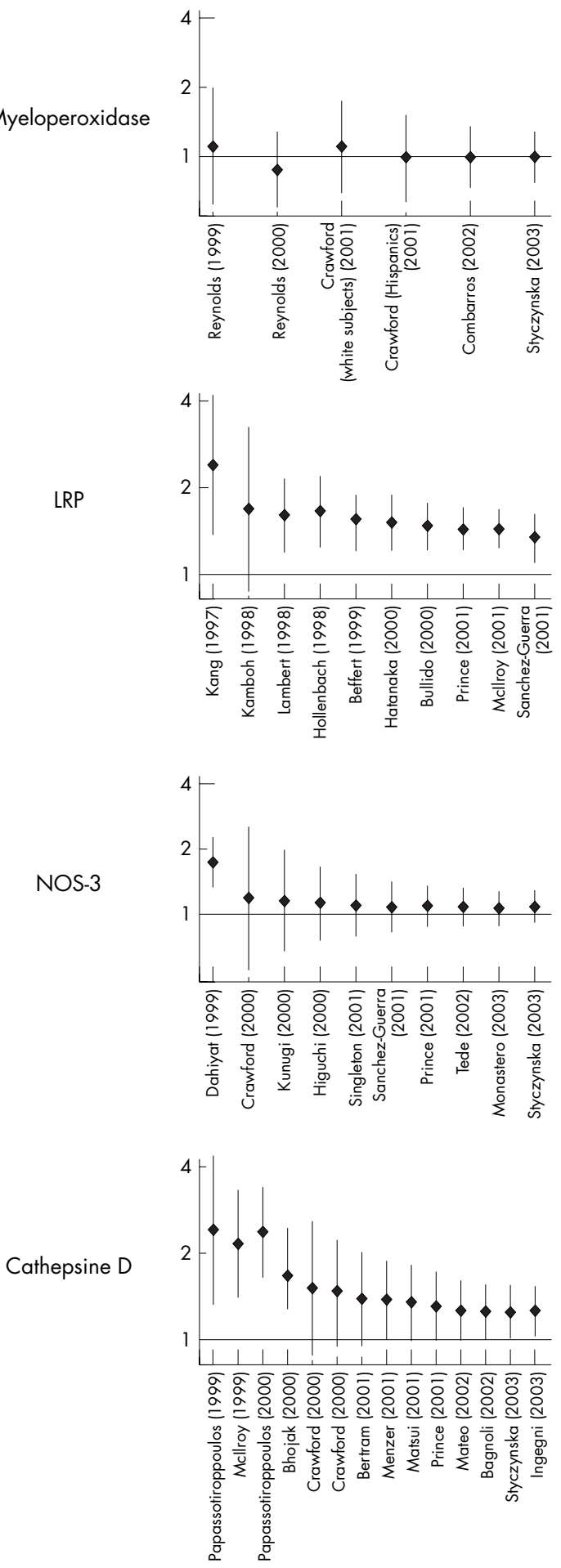

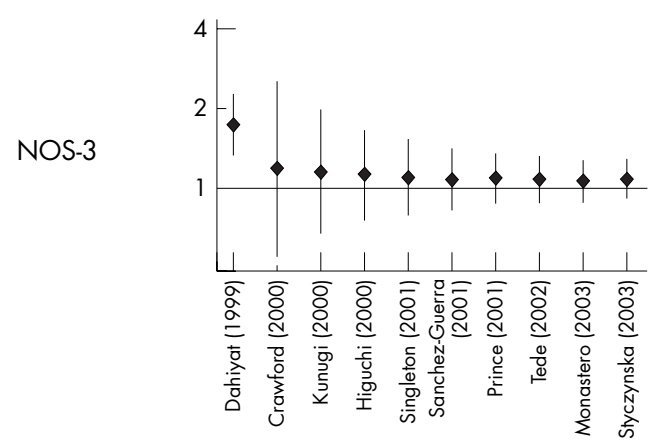

NOS-3

LRP
Figure 1 Odds ratios and 95\% confidence intervals for the individual studies (left column) and the cumulative meta-analyses (right column).
Authors' affiliations

J Llorca, T Dierssen-Sotos, Division of Preventive Medicine and Public Health, University of Cantabria School of Medicine, Spain

O Combarros, J Berciano, Service of Neurology, University Hospital Marqués de Valdecilla, Santander, Spain

Funding: none.

Conflicts of interest: none declared.

Correspondence to: Dr J Llorca, Medicina Preventiva y Salud Pública, Avda Cardenal Herrera Oria s/n, 39011 Santander, Spain;

llorcaj@unican.es
Accepted for publication 4 May 2004

\section{REFERENCES}

1 loannidis JPA, Ntzani EE, Trikalinos TA, et al. Replication validity of genetic association studies. Nature Genet 2001;29:306-9.

2 Combarros O, Alvarez-Arcaya A, Sanchez-Guerra M, et al. Association study of 10 candidate genes with sporadic Alzheimer's disease in a Spanish population. Curr Med Chem Immunol Endoc Metab Agents 2002;2:163-73.

3 Combarros $\mathrm{O}$, Infante J, Llorca J, et al. The myeloperoxidase gene in Alzheimer's disease: a case-control study and meta-analysis. Neurosci Lett 2002;326:33-6. 
4 Reynolds WF, Rhees J, Maciejewski D, et al. Myeloperoxidase polymorphism is associated with gender specific risk for Alzheimer's disease. Exp Neurol 1999; 155:31-41.

5 Reynolds WF, Hiltunen $M$, Priskanen $M$, et al. MPO and $A P O E \in 4$ polymorphisms interact to increase risk for $A D$ in Finnish males. Neurology 2000;55:1284-90.

6 Crawford FC, Freeman MJ, Schinka JA, et al. Association between Azlheimer's disease and a functional polymorphism in the myeloperoxidase gene. Exp Neurol 2001;167:456-9.

7 Combarros O, Infante J, Llorca J, et al. The myeloperoxidase gene in Alzheimer's disease: a case-control study and meta-analysis. Neurosci Lett 2002;326:33-6.

8 Styczynska M, Religa D, Pfeffer A, et al. Simultaneous analysis of five genetic risk factors in Polish patients with Alzheimer's disease. Neurosci Lett 2003;344:99-102.

9 Kang DE, Saitoh T, Chen X, et al. Genetic association of the low-density lipoprotein receptor-related protein gene (LRP), an apolipoprotein $E$ receptor, with late-onset Alzheimer's disease. Neurology 1997;49:56-61.

10 Kamboh MI, Ferrel RE, DeKosky ST. Genetic association studies between Alzheimer's disease and two polymorphisms in the low density lipoprotein receptor-related protein gene. Neurosci Lett 1998;244:65-8.

11 Lambert JC, Wavrant-De Vrieze F, et al. Association at LRP gene locus with sporadic late-onset Alzheimer's disease. Lancet 1998;351:1787-8.

12 Hollenbach $\mathrm{E}$, Ackermann $\mathrm{S}$, Hyman BT, et al. Confirmation of an association between a polymorphism in exon 3 of the low-density lipoprotein receptorrelated protein gene and Alzheimer's disease. Neurology 1998;50:1905-7.

13 Beffert U, Arguin C, Poirier J. The polymorphism in exon 3 of the low density lipoprotein receptor-related protein gene is weakly associated with Alzheimer's disease. Neurosci Lett 1999;88:136-9.

14 Bullido MJ, Guallar-Castillon P, Artiga MJ, et al. Alzheimer's risk associated with human apolipoprotein $\mathrm{E}$, alpha-2 macroglobulin and lipoprotein receptor related protein polymorphisms: absence of genetic interactions, and modulation by gender. Neurosci Lett 2000;289:213-16.

15 Hatanaka Y, Kamino K, Fukuo K, et al. Low density lipoprotein receptorrelated protein gene polymorphisms and risk for late-onset Alzheimer's disease in a Japanese population. Clin Genet 2000;58:319-23.

16 Prince JA, Feuk L, Sawyer SI, et al. Lack of replication of association findings in complex disease: an analysis of 15 polymorphisms in prior candidate genes for sporadic Alzheimer's disease. Eur J Hum Genet 2001;9:437-44.

17 Mcllroy SP, Dynnan KB, Vahidassr DJ, et al. Common polymorphisms in LRP and $A 2 M$ do not affect genetic risk for Alzheimer disease in Northern Ireland. Am J Med Genet 2001; 105:502-6.

18 Sanchez-Guerra M, Combarros O, Infante J, et al. Case-control study and meta-analysis of low density lipoprotein receptor-related protein gene exon 3 polymorphism in Alzheimer's disease. Neurosci Lett 2001;316:17-20.

19 Dahiyat M, Cumming A, Harrington C, et al. Association between Alzheimer's disease and the NOS3 gene. Ann Neurol 1999;46:664-7.

20 Crawford F, Freeman M, Abdullah L, et al. No association between the NOS3 codon 298 polymorphism and Alzheimer's disease in a sample from the United States. Ann Neurol 2000;47:687.

21 Kunugi $H$, Akahane A, Ueki A, et al. No evidence for an association between the Glu298Asp polymorphism of the NOS3 gene and Alzheimer's disease. J Neural Transm 2000;107:1081-4.

22 Higuchi S, Ohta S, Matsuita S, et al. NOS3 polymorphism not associated with Alzheimer's diseasae in Japanese. Ann Neurol 2000;48:685.
23 Singleton AB, Gibson AM, McKeith IG, et al. Nitric oxide synthase gene polymorphisms in Alzheimer's disease and dementia with Lewy bodies. Neurosci Lett 2001;303:33-6.

24 Sanchez-Guerra M, Combarros O, Alvarez-Arcaya A, et al. The Glu298Asp polymorphism in the NOS3 gene is not associated with sporadic Alzheimer's disease. J Neurol Neurosurg Psychiatry 2001;70:556-7.

25 Tedde A, Nacmias B, Cellini E, et al. Lack of association between NOS3 polymorphism and Italian sporadic and familial Alzheimer's disease. J Neurol 2002;249:110-11.

26 Monastero R, Cefalu AB, Camarda C, et al. No association between Glu298Asp endothelial nitric oxide synthase polymorphism and Italian sporadic Alzheimer's disease. Neurosci Lett 2003;341:229-32.

27 Papassotiropoulos A, Bagli M, Feder O, et al. Genetic polymorphism of cathepsin $D$ is strongly associated with the risk for developing sporadic Alzheimer's disease. Neurosci Lett 1999;262:171-4.

28 Mcllroy SP, Dynan KB, McGleenon BM, et al. Cathepsin D gene exon 2 polymorphism and sporadic Alzheimer's disease. Neurosci Lett 1999;273:140-1

29 Papassotiropoulos A, Bagli M, Kurz A, et al. A genetic variation of cathepsin $D$ is a major risk factor for Alzheimer's disease. Ann Neurol 2000;47:399-403.

30 Bhojak TJ, Dekosky ST, Ganguli M, et al. Genetic polymorphisms in the cathepsin D and interleukin- 6 genes and the risk of Alzheimer's disease. Neurosci Lett 2000;288:21-4.

31 Crawford FC, Freeman MJ, Schinka J, et al. The genetic association between cathepsin D and Alzheimer's disease. Neurosci Lett 2000;289:61-5.

32 Bertram L, Guenette S, Jones J, et al. No evidence for genetic association or linkage of the cathepsin D (CTSD) exon 2 polymorphism and Alzheimer disease. Ann Neurol 2001:49:114-16.

33 Menzer G, Muller-Thomsen T, Meins W, et al. Non-replication of association between cathepsin D genotype and late onset Alzheimer disease. Am J Med Genet 2001;105:179-82.

34 Matsui T, Morikawa Y, Tojo M, et al. Cathepsin D polymorphism not associated with Alzheimer's disease in Japanese. Ann Neurol 2001;49:544-5.

35 Mateo I, Sanchez-Guerra M, Combarros $O$, et al. Lack of association between cathepsin D genetic polymorphism and Alzheimer disease in a Spanish sample. Am J Med Genet 2002;114:31-3.

36 Bagnoli S, Nacmias B, Tedde A, et al. Cathepsin D polymorphism in Italian sporadic and familial Alzheimer's disease. Neurosci Lett 2002;328:273-6

37 Ingegni T, Nocentini G, Mariani E, et al. Cathepsin D polymorphim in Italian elderly subjects with sporadic late-onset Alzheimer's disease. Dement Geriatr Cogn Disord 2003;16:151-5.

38 Baum L, Chen L, Ng HK, et al. Low density lipoprotein receptor related protein gene exon 3 polymorphism association with Alzheimer's disease in Chinese. Neurosci Lett 1998;247:33-6.

39 Dickersin K, Min Y-I, Meinert CL. Factors influencing publication of research results: follow-up of applications submitted to two institutional review boards. JAMA 1992;267:374-8

40 Rothman KJ, Greenland S. Hill's criteria for causality. In: Gail MH, Benichou J, eds. Encyclopedia of epidemiologic methods. Chichester: Wiley, 2000:428-31.

41 Ntais C, Plycarpou A, loannidis JPA. Meta-analysis of the association of the cathepsin D Ala224Val gene polymorphism with the risk of Alzheimer's disease: a HuGe gene-disease association review. Am J Epidemiol 2004; 159:527-36. 